\title{
One-Dimensional Copper(II) Coordination Polymer as an Electrocatalyst for Water Oxidation
}

\author{
Rupali Mishra, ${ }^{[a]}$ Emine Ülker, $^{[a, b]}$ and Ferdi Karadas ${ }^{*[a, c]}$
}

\begin{abstract}
Although cobalt-based heterogeneous catalysts are the central focus in water oxidation research, interest in copper-based water oxidation catalysts has been growing thanks the great abundance of copper and its biological relevance. Several copper oxides have recently been reported to be active catalysts for water oxidation. In this study, a heterogeneous copper-based water oxidation catalyst that is not an oxide has been reported for the first time. Single-crystal XRD studies indicate that the compound is a one-dimensional coordination
\end{abstract}

compound incorporating copper paddle-wheel units connected through phosphine dioxide ligands. The catalyst exhibits an onset potential of $372 \mathrm{mV}$ at $\mathrm{pH} 10.2$, whereas an overpotential of only $563 \mathrm{mV}$ is required to produce a current density of $1 \mathrm{~mA} \mathrm{~cm}^{-2}$. In addition to cyclic voltammetric and chronoamperometric studies, an investigation into the effect of $\mathrm{pH}$ on the catalytic activity and the robustness of the catalyst using long-term bulk electrolysis ( $12 \mathrm{~h}$ ) is presented.

\section{Introduction}

Significant efforts have been devoted to electrocatalytic splitting of water, particularly in the last two decades, to implement hydrogen economy as a renewable and clean alternative to fossil fuels. One of the main challenges in the pursuit of this task is to develop efficient, robust, and inexpensive catalysts for the water oxidation half reaction, which involves a $4 \mathrm{H}^{+} / 4 \mathrm{e}^{-}$process with relatively high potential $[E=0.82 \mathrm{~V}$, pH 7 vs. NHE, $25^{\circ} \mathrm{C}$; Eq. (1)]:

$2 \mathrm{H}_{2} \mathrm{O} \rightarrow \mathrm{O}_{2}+4 \mathrm{H}^{+}+4 \mathrm{e}^{-}$

Although oxides of precious metals, such as $\mathrm{RuO}_{2}{ }^{[1]}$ and $\mathrm{IrO}_{2}{ }^{\left[{ }^{[2]}\right.}$ exhibit high performance in the oxygen evolution reaction, the main focus in this field has been the investigation of compounds incorporating $3 \mathrm{~d}$ metal ions (particularly $\mathrm{Co}^{[3]}$ $\mathrm{Mn}^{[4]}$ and $\left.\mathrm{Ni}\right) .{ }^{[5]}$ Some of the benchmark studies include the cobalt phosphate (Co-Pi) catalyst ${ }^{[6]}$ cobalt polyoxometalates $(\mathrm{Co}-\mathrm{POM}){ }^{[7]}\left[\mathrm{NiO}(\mathrm{OH}){ }^{[8]}\right.$ and birnessite-type $\mathrm{MnO}_{2}{ }^{[9]}$

Recently water oxidation catalysts (WOCs) containing copper have also received attention, as copper is the second most earth-abundant metal and it is biologically relevant considering the key role it has in several oxidation processes such as those

[a] Dr. R. Mishra, Prof. E. Ülker, Prof. F. Karadas

Department of Chemistry, Bilkent University

06800 Ankara (Turkey)

E-mail:karadas@fen.bilkent.edu.tr

[b] Prof. E. Ülker

Department of Chemistry, Faculty of Arts \& Sciences Recep Tayyip Erdogan University, 53100 Rize (Turkey)

[c] Prof. F. Karadas

Institute of Materials Science and Nanotechnology (UNAM) Bilkent University, 06800 Ankara (Turkey)

$\square$ Supporting Information and the ORCID identification number(s) for the

(iD) author(s) of this article can be found under http://dx.doi.org/10.1002/ celc. 201600518. involving methane monooxygenase ${ }^{[10]}$ and cytochrome $c$ oxidase. ${ }^{[11]}$ The portfolio of WOCs containing copper involves various compounds ranging from homogeneous molecular complexes such as Cu-bipyridine, ${ }^{[12]}$ copper carbonates, ${ }^{[13]}$ and $\mathrm{Cu}_{-}$ tetrapeptide $^{[14]}$ systems to three-dimensional heterogeneous copper oxides. ${ }^{[15]}$ In 2012, Mayer et al. reported the first example of a homogeneous copper electrocatalyst for water oxidation with a simple formula of $\left[(b p y) C u(O H)_{2}\right]$ (bpy $=2,2^{\prime}$-bipyridine). ${ }^{[12]}$ Lin et al. later reported that substitution of the bpy ligand with 6,6'-dihydroxy-2,2'-bipyridine leads to a significant increase in the catalytic activity due to ligand oxidation. ${ }^{[16]}$ By contrast, several studies performed on copper oxide systems suggest that copper(II) ions surrounded by oxygen atoms can also electrocatalytically oxidise water. ${ }^{[1]]}$ Moreover, the investigation of water oxidation performance of different copper(II) salts in the presence of carbonate or phosphate buffers indicates that the ligands around the metal ion play a key role in the robustness and the catalytic activity of copper ions. ${ }^{[13]}$ Given the aforementioned study, our recent efforts have been concentrated on decorating the coordination sphere of the $\mathrm{Cu}^{\text {Il }}$ site with oxygen groups that belong to acetate and phosphorus-containing ligands, which are stable at anodic potentials. Whereas phosphines are suitable coordinating ligands particularly for low-valent metal ions due to their strong $\sigma$-donating ability, phosphine oxides could also be used for coordination to metal sites. ${ }^{[18]}$ Coordination compounds based on dinuclear copper acetate groups, also known as copper paddlewheel complexes, have been reported previously. Copper-acetate-based coordination polymers have received attention in the fields of magnetism, ${ }^{[19]}$ gas adsorption, ${ }^{[20]}$ and biology ${ }^{[21]}$ mainly due to the stability and structural integrity of paddlewheel systems.

Our preliminary studies show that copper acetate in aqueous solution exhibits significant catalytic activity at anodic po- 
tentials (Figure S1 in the Supporting Information). Because heterogeneous catalysts have several advantages over homogeneous catalysts, such as easy implementation and higher stability, our research efforts have recently focused on obtaining heterogeneous WOCs that incorporate copper paddle-wheel groups. In this study, the synthesis, crystal structure, and characterisation of a novel 1D copper(II) coordination polymer, abbreviated as $\left[\mathrm{Cu}_{2}-\mathrm{P}_{\mathrm{o}}\right]_{n}$, are reported. Electrochemical and electrocatalytic water oxidation studies performed on fluorine-doped tin oxide (FTO) electrodes coated with the compound, as well as longterm $(12 \mathrm{~h})$ catalytic studies and characterisation studies on the pristine and post-catalytic electrodes are also reported in detail.

\section{Results and Discussion}

\subsection{Synthesis and Crystal Structure}

The phosphine dioxide ligand used in this study was synthesised by oxidising 1,2-bis(diphenylphosphino)ethane with hydrogen peroxide. The reaction of phosphine dioxide with copper acetate in a methanol/dichloromethane mixture led to the formation of dark blue crystals. The structure of $\left[\mathrm{Cu}_{2}-\mathrm{P}_{\mathrm{o}}\right]_{n}$ was successfully solved and converged in the monoclinic space group P121/n1. Crystallographic data and structural refinement parameters for the compound are given in Table S1. The crystal structure of $\left[\mathrm{Cu}_{2}-\mathrm{P}_{\mathrm{o}}\right]_{n}$ consists of centrosymmetric dimeric molecules with $\left[\mathrm{Cu}_{2}(\mu-\mathrm{OAc})_{4}\right](\mathrm{OAc}=$ acetate $)$ units linked to each other with 1,2-bis(diphenylphosphino)ethane dioxide $\left(P_{o}\right)$ bridging groups through copper(II) sites (Figure 1). The bridging ligand $\mathrm{P}_{0}$ is connected to copper paddle-wheel units in a monodentate fashion (Figure 2). The asymmetric unit of the crystal structure contains one copper(II) paddle-wheel group with half occupancy and one ligand unit, $\mathrm{P}_{\mathrm{o}}$. The crystal

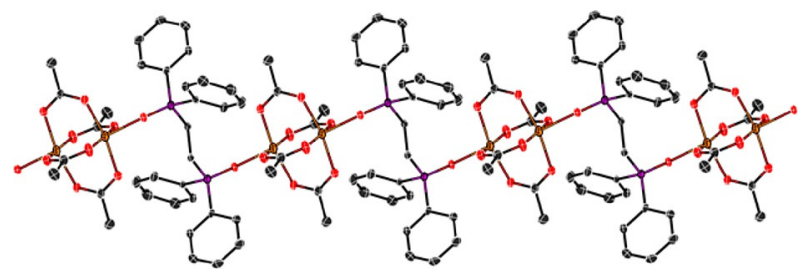

Figure 1. 1D chain structure of $\left[\mathrm{Cu}_{2}-\mathrm{P}_{\mathrm{o}}\right]_{n}$. Colour code: $\mathrm{Cu}=$ orange; $\mathrm{P}=$ purple; $\mathrm{O}=$ red; $\mathrm{C}=$ grey $\mathrm{N}=$ blue. Thermal ellipsoids are projected at the $50 \%$ probability level. Hydrogen atoms are not shown for clarity.

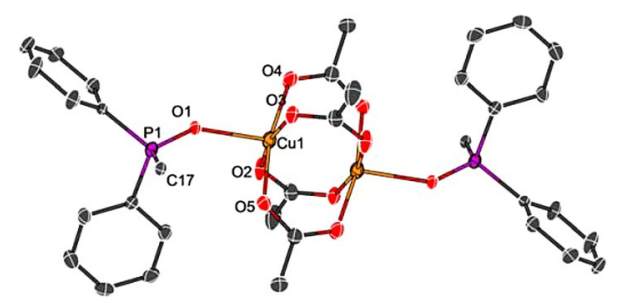

Figure 2. Structure of a segment of the chain in $\left[\mathrm{Cu}_{2}-\mathrm{P}_{0}\right]_{n}$, showing only one copper paddle-wheel unit. structure of $\left[\mathrm{Cu}_{2}-\mathrm{P}_{0}\right]_{n}$, thus, could best be described as 1D zigzag chains that consists of independent $\left[\mathrm{Cu}_{2}(\mu-\mathrm{AcO})_{4}\right]$ paddle-wheel units linked by $\mathrm{P}_{\mathrm{o}}$ bridging groups. Each metal ion is surrounded by five oxygen atoms, one of which is the oxygen of the phosphine dioxide ligand, whereas the other four belong to acetate bridging groups, thus the complex adopts a square pyramidal coordination environment. In each paddle-wheel unit, the $\mathrm{Cu}$...Cu distance is $2.658 \AA$. All of the $\mathrm{Cu}-\mathrm{O}$ distances are within the normal ranges allowing for statistical errors (Table S1). ${ }^{[22]}$ The packing diagram of the compound depicting the arrangement of the 1D chains with respect to each other is shown in Figure S2.

\subsection{Electrocatalytic Water Oxidation}

Cyclic voltammetry (CV) studies were performed to investigate the electrochemical behaviour of $\left[\mathrm{Cu}_{2}-\mathrm{P}_{\mathrm{o}}\right]_{n}$-modified FTO electrodes in $\mathrm{KBi}$ solution at different $\mathrm{pH}$ values. $\mathrm{CV}$ revealed an onset oxidative catalytic current wave, which is attributed to catalytic $\mathrm{O}_{2}$ evolution, at $1.05 \mathrm{~V}$ at $\mathrm{pH} 9.2$ (Figure 3). As the basicity of the medium is increased gradually from $\mathrm{pH} 9.2$ to 12.2 the onset potential of the aforementioned wave shifts from approximately 1.05 to $0.9 \mathrm{~V}$, whereas the current density obtained at $1.5 \mathrm{~V}$ (vs. $\mathrm{Ag} / \mathrm{AgCl}$ ) increases from approximately 2 to $6.5 \mathrm{mAcm}^{-2}$. The plot in Figure 3 (black) that represents the bare FTO electrode shows no appreciable catalytic wave, indicating that the presence of $\left[\mathrm{Cu}_{2}-\mathrm{P}_{\mathrm{o}}\right]_{n}$ on the FTO electrode is essential for the catalytic reaction.

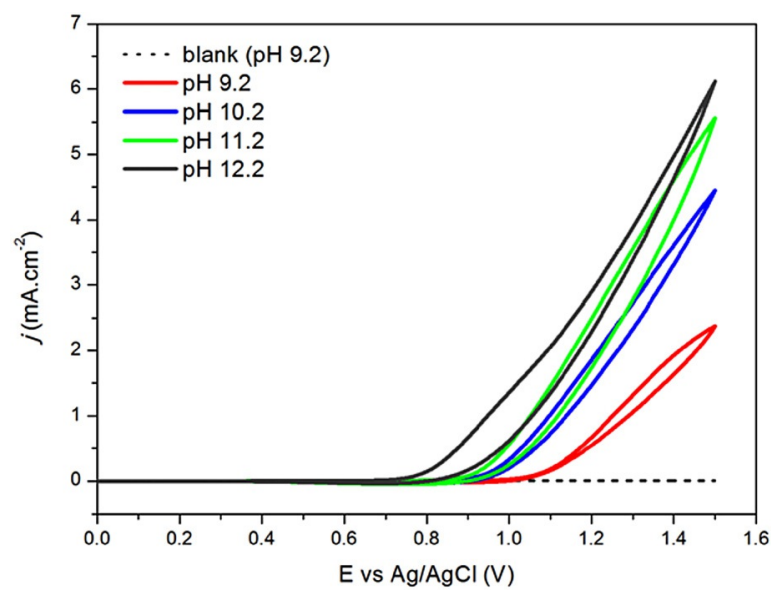

Figure 3. Cyclic voltammograms of the $\left[\mathrm{Cu}_{2}-\mathrm{P}_{0}\right]_{n}$-modified FTO electrode recorded in $0.1 \mathrm{M} \mathrm{KBi}$ electrolyte at different $\mathrm{pH}$, recorded at a $50 \mathrm{mV} \mathrm{s}^{-1}$ sweep rate. The blank measurement (dashed line) was obtained by using bare FTO as the working electrode.

Chronoamperometric studies were then performed to investigate the catalytic activity of $\left[\mathrm{Cu}_{2}-\mathrm{P}_{\mathrm{o}}\right]$-modified FTO electrodes in detail. A linear Tafel plot in the range 353-593 mV was obtained at pH 9.2 using $\mathrm{KBi}$ as an electrolyte (Figure 4). A slope of $71 \mathrm{mV} \mathrm{dec}^{-1}$ was obtained, which suggests a mechanism involving a one-electron chemical pre-equilibrium step that precedes the rate-limiting step. ${ }^{[23]}$ The plot also reveals an onset 


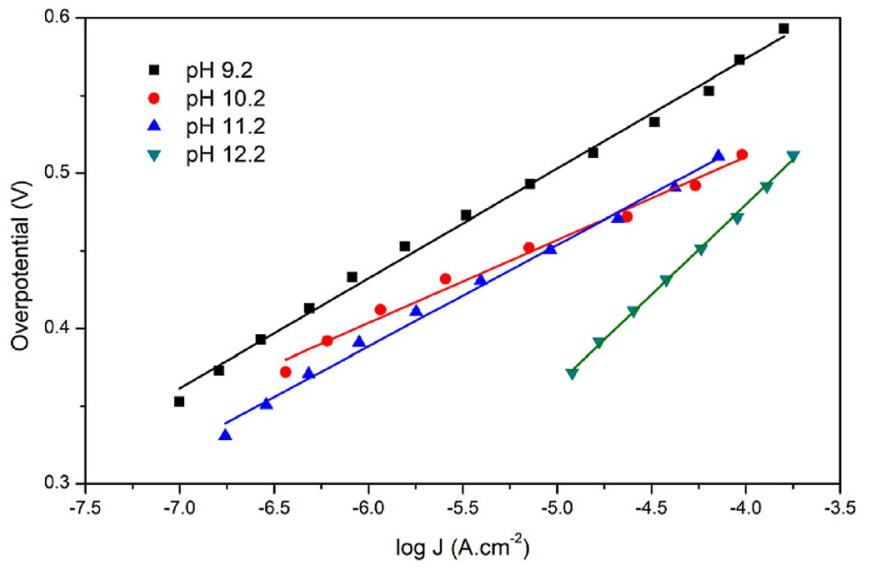

Figure 4. Tafel plots for $\left[\mathrm{Cu}_{2}-\mathrm{P}_{0}\right]_{n}$-modified FTO electrodes obtained at different $\mathrm{pH} . \mathrm{Ag} / \mathrm{AgCl}$ was used as reference electrode and $0.1 \mathrm{M} \mathrm{KBi}$ was used as the electrolyte. Tafel slopes of $71,54,65$, and $116 \mathrm{mV} \mathrm{dec}^{-1}$ were obtained at $\mathrm{pH}$ values of $9.2,10.2,11.2$, and 12.2 , respectively.

potential of $353 \mathrm{mV}$ and overpotentials of 644 and $715 \mathrm{mV}$ were required to produce current densities of 1 and $10 \mathrm{~mA} \mathrm{~cm}^{-2}$, respectively. Chronoamperometric studies were also performed at different $\mathrm{pH}$ to investigate the effect of $\mathrm{pH}$ on the mechanism of water oxidation. As the $\mathrm{pH}$ increases from 9.2 to 11.2, the Tafel slope decreases slightly to approximately $60 \mathrm{mV} \mathrm{dec}^{-1}$ and then sharply increases to $116 \mathrm{mV} \mathrm{dec}^{-1}$. This trend suggests that the catalytic oxidation mechanism exhibits similar behaviour at $\mathrm{pH}$ 9.2-11.2, whereas the high slope at $\mathrm{pH} 12.2$ could be attributed to a change in the rate-determining step of the water oxidation process. Tafel plots also indicate that the catalyst exhibits the best performance at $\mathrm{pH} 10.2$ with an onset potential of $372 \mathrm{mV}$ and overpotentials of 563 and $617 \mathrm{mV}$ were required to produce current densities of 1 and $10 \mathrm{mAcm}^{-2}$, respectively. Although the origin of catalytic water oxidation is beyond the scope of this study, the 1D structure implies that copper(II) sites of the paddle-wheel units on the electrode surface, which reside at the end of each chain, that is, the square pyramidal copper(II) sites coordinated to water molecules instead of phosphine dioxide groups, act as oxygen-evolving centres. The catalytic efficiency of the compound is in accordance with previously studied copper-based WOCs (Table S3). Tafel slopes of copper oxides are generally in the range of $54-62 \mathrm{mV} \mathrm{dec}^{-1}$, whereas it is higher for $\mathrm{CuCO}_{3},{ }^{[24]}[\mathrm{Bi}]^{[25]} \mathrm{O}_{2}-\mathrm{CuCat},{ }^{[26]}$ and $\mathrm{Cu}-(\mathrm{TEOA})$ $\left(\mathrm{TEO}=\right.$ triethanolamine $^{[27]}$ systems. If the overpotential required for $1 \mathrm{~mA} \mathrm{~cm}^{-2}$ is compared, the catalyst exhibits better performance than $\mathrm{CuO}$ (TPA) (TPA = tripropylamine), $\mathrm{O}_{2}-\mathrm{CuCat}$, and $\mathrm{Cu}-\mathrm{TEOA}$. The similarity in Tafel slopes between $\left[\mathrm{Cu}_{2}-\mathrm{P}_{\mathrm{o}}\right]_{n}$ and copper oxides suggests that the mechanism for water oxidation involves the formation of a peroxide intermediate. ${ }^{[13]}$

Bulk electrolysis was performed in the presence of an oxygen-sensing probe to monitor the $\mathrm{O}_{2}$ evolution quantitatively. The amount of $\mathrm{O}_{2}$ produced during the course of $2 \mathrm{~h}$ of electrolysis recorded by the probe and the theoretical amount of evolved $\mathrm{O}_{2}$ extracted from the total charge are plotted in (Figure 5). The similarities of the two curves clearly indicate

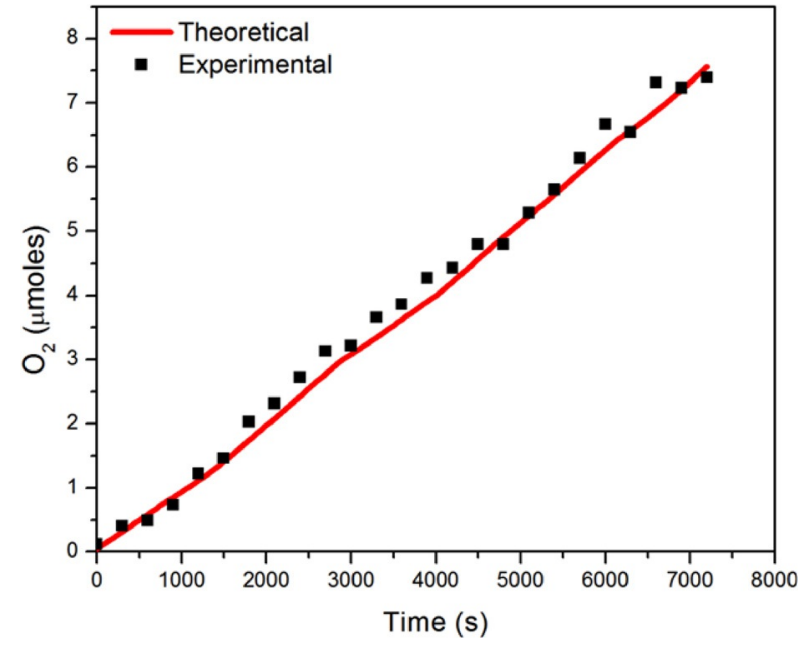

Figure 5. Faradic efficiency of the $\left[\mathrm{Cu}_{2}-\mathrm{P}_{\mathrm{o}}\right]_{n}$-modified FTO electrode measured by an oxygen-sensor system. Bulk electrolysis was performed at $1.1 \mathrm{~V}$ vs. $\mathrm{Ag} / \mathrm{AgCl}$ at $\mathrm{pH} 9.2$ in $\mathrm{KBi}$ solution in a gas-tight electrochemical cell. The amount of dissolved $\mathrm{O}_{2}$ molecules detected during bulk electrolysis and the theoretical amount of evolved $\mathrm{O}_{2}$ assuming a Faradaic efficiency of $100 \%$ are represented by the black data points and red line, respectively. A buffer solution of $130 \mathrm{~mL}$ was used for experiments. $\mathrm{O}_{2}$ content was recorded in units of $\mathrm{mg} \mathrm{L}^{-1}$ and converted to micromoles of $\mathrm{O}_{2}$.

that the only origin of current is a catalytic water oxidation process.

Long-term chronoamperometric studies were also performed to investigate the stability of the catalyst. A potential of $1.1 \mathrm{~V}$ ( $\mathrm{vs} . \mathrm{Ag} / \mathrm{AgCl}$ ) was applied for $12 \mathrm{~h}$. The current density was maintained at approximately $270 \mu \mathrm{Acm}^{-2}$ throughout the measurement, suggesting high durability in the applied conditions (Figure 6). An initial increase in the current density could be attributed to morphological changes on the surface of the electrode similar to those of previously reported copper-based

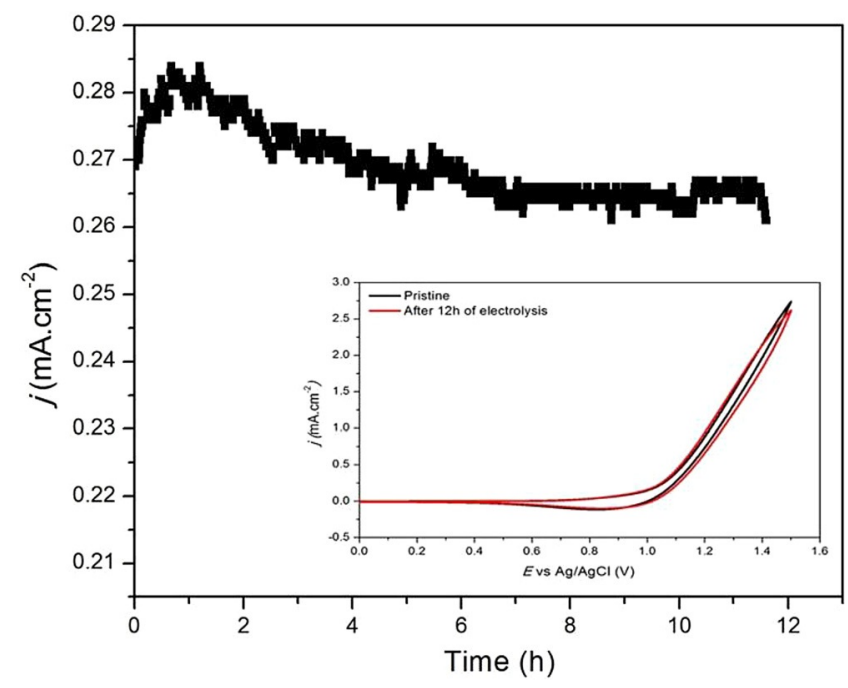

Figure 6. Long-term electrolysis studies for the $\left[\mathrm{Cu}_{2}-\mathrm{P}_{\mathrm{o}}\right]_{n}$-modified FTO electrode, performed at $1.1 \mathrm{~V}(\mathrm{vs}$. $\mathrm{Ag} / \mathrm{AgCl})$ in $0.1 \mathrm{M} \mathrm{KBi}$ electrolyte at $\mathrm{pH}$ 9.2. Inset: Cyclic voltammograms of the $\left[\mathrm{Cu}_{2}-\mathrm{P}_{0}\right]_{n}$-modified FTO electrode immediately prior to and after $12 \mathrm{~h}$ electrolysis. 
WOCs. ${ }^{[26]}$ Stability of the electrode was also confirmed by the comparison of cyclic voltammograms of the electrodes recorded before and after electrolysis for $12 \mathrm{~h}$ (Figure 6, inset). No significant change in the catalytic current was observed after electrolysis and CV profiles are identical, suggesting high stability of the catalysts (a slight decrease in the peak current can be attributed to the mechanical loss of the catalyst from the surface during catalysis).

\subsection{Characterisation}

The percentage weight of carbon and hydrogen obtained by elemental analysis of powder sample was in excellent agreement with the molecular formula of the crystal structure, which indicates that the crystal is truly representative of the bulk phase. The chemical integrity of the catalyst deposited on a FTO electrode was investigated with X-ray photoelectron spectroscopy (XPS) and X-ray diffraction (XRD) techniques. XRD patterns of pristine and post-catalytic electrodes (obtained after $2 \mathrm{~h}$ of bulk electrolysis at $\mathrm{pH} 9.2$ and $1.1 \mathrm{~V}$ vs. $\mathrm{Ag} / \mathrm{AgCl}$ ) were identical and no additional peaks were observed, indicating the chemical integrity of the catalyst during the catalytic process (Figure S4).

XPS survey spectra of both pristine and post-catalytic samples (Figure 7) reveal the catalyst mainly gives Cu 2p, O 1s, C 1s, and $\mathrm{P} 2 \mathrm{p}$ signals, as expected. The high-resolution $\mathrm{C} 1 \mathrm{~s}$ spec-
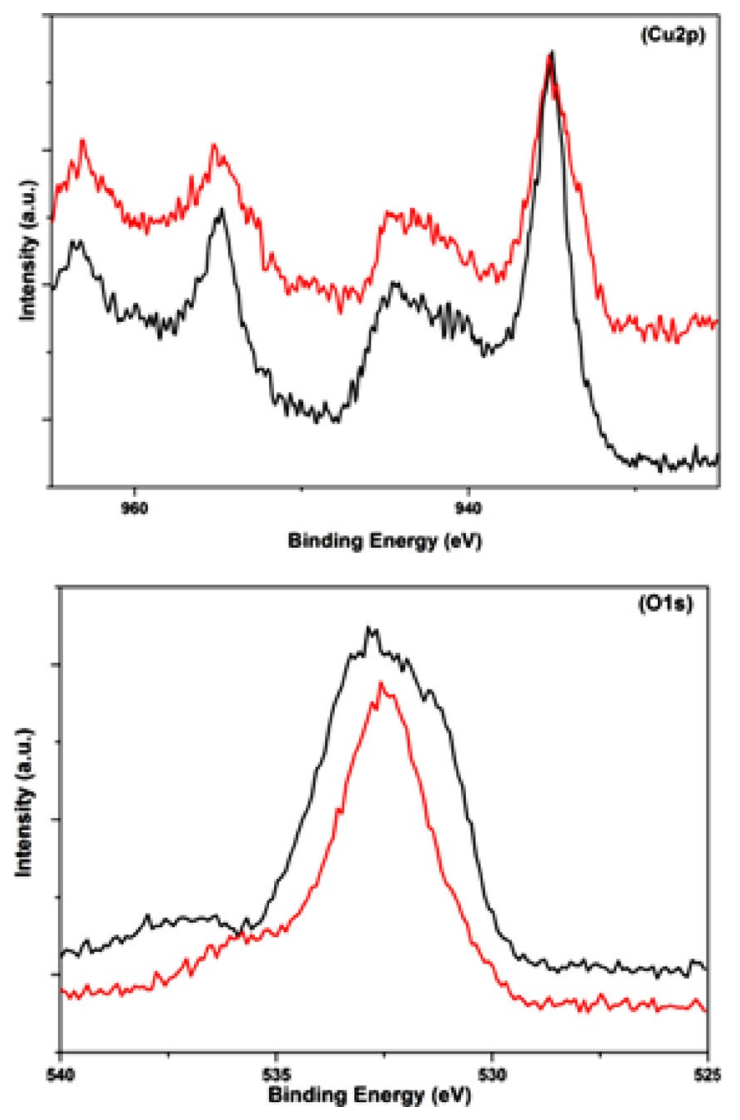

Figure 7. High-resolution XPS spectra of a) Cu 2p and b) O 1s regions for pristine (black) and post-catalytic (red) electrodes. trum contains a broad signal between 284.2 to $287.4 \mathrm{eV}$, indicating the presence of carbon in different environments. ${ }^{[28]}$ The P $2 p$ spectrum shows a single peak at $133.3 \mathrm{eV}$ (Figure S5), which can be ascribed to the phosphorus atom of the phosphine oxide ligand. ${ }^{[29]}$ Both the pristine and the post-catalytic samples exhibit broad $\mathrm{Cu} 2 \mathrm{p}$ signals (full width at half-maximum $\approx 3-6 \mathrm{eV}$ ) between 928 and $965 \mathrm{eV}$ that can be attributed to $\mathrm{Cu} 2 \mathrm{p}_{3 / 2}$ and $\mathrm{Cu} 2 \mathrm{p}_{1 / 2}$ peaks, respectively; these correspond to $\mathrm{Cu}^{2+}$ species $\left(933.9\right.$ and $955.2 \mathrm{eV}$ ). ${ }^{[30]}$ Satellite peaks observed at $8-10 \mathrm{eV}$ above the principle peaks support the presence of a partially filled $\mathrm{Cu} 3 \mathrm{~d}^{9}$ shell. ${ }^{[26,31]} \mathrm{A}$ broad intense peak of $\mathrm{O} 1 \mathrm{~s}$ between 530.50 and $534.24 \mathrm{eV}$ can be assigned to different types of oxygen atoms. The peak at $530.7 \mathrm{eV}$ corresponds to the $\mathrm{P}=\mathrm{O}^{[32]}$ bond, whereas that at around $533.4 \mathrm{eV}$ could be assigned to the $\mathrm{C}=\mathrm{O}$ of the copper paddle-wheel unit (Figure S4). ${ }^{[3,34]}$ The absence of any scalable shift in the signal positions in the post-catalytic sample suggests that there is no oxide formation on the surface during the catalysis. The Raman spectrum for the $\mathrm{Cu}$ compound reveals a $\mathrm{CuO}_{x} \mathrm{Ag}$ band at approximately $295 \mathrm{~cm}^{-1[35]}$ and a peak at $1700 \mathrm{~cm}^{-1}$, which is the $\mathrm{G}$ band of oxygen (Figure $\mathrm{S6}$ ). The Raman frequencies are consistent with data for pure single-phase $\mathrm{CuO}_{x}$ films having a high degree of crystallinity.

\section{Conclusions}

In summary, this study provides a novel example of the use of a copper paddle-wheel system as a heterogeneous WOC. The catalyst required overpotentials of 563 and $617 \mathrm{mV}$ to produce current densities of 1 and $10 \mathrm{~mA} \mathrm{~cm}^{-2}$, respectively, at $\mathrm{pH} 10.2$. Chronoamperometric measurements were performed also at different $\mathrm{pH}$ values to elucidate the mechanism of catalysis. A Tafel slope of approximately $60 \mathrm{mV} \mathrm{dec}^{-1}$ at $\mathrm{pH}$ 9.2-11.2 suggests a mechanism involving a one-electron chemical pre-equilibrium step preceding the rate-limiting step, and the increase in Tafel slope to $116 \mathrm{mV} \mathrm{dec}^{-1}$ at $\mathrm{pH} 12.2$ could be attributed to a change in the rate-determining step of the water oxidation process. The catalyst retained its structure even during $12 \mathrm{~h}$ of electrolysis, which was confirmed by XRD, XPS, and Raman techniques, owing to the stability and robustness of the system provided by acetate and phosphine dioxide groups. It is believed that copper(II) sites with square pyramidal geometries on the electrode surface, which are coordinated to water molecules instead of phosphine dioxide ligands, are responsible for the electrocatalytic water oxidation process.

Recently, several copper oxides prepared mainly by the electrolysis of copper(II) salts and complexes in the presence of different electrolytes have been reported to have promising catalytic activities. This study shows that a copper-based coordination compound, rather than an oxide, could also serve as an efficient WOC, and new compounds should be introduced to investigate the ideal coordination sphere for the copper(II) site. Our further studies will focus on new copper paddle-wheel compounds with different coordinating bridging ligands as WOCs to study the effect of such ligands on the surface concentration and, thus, their effect on catalytic activity. 


\section{Experimental Section}

\section{Materials}

1,2-Bis(diphenylphosphino)ethane [1,2-bis(DPPE)], copper acetate monohydrate $\left[\mathrm{Cu}(\mathrm{OAC})_{2} \cdot \mathrm{H}_{2} \mathrm{O}\right]$, hydrogen peroxide, ethanol, methanol, and dichloromethane were acquired from Sigma-Aldrich and used as received. All solvents were purified prior to use. KBi electrolyte solutions were prepared by mixing approximate volumes of $\mathrm{KOH}(0.1 \mathrm{M})$ and $\mathrm{H}_{3} \mathrm{BO}_{3}(0.1 \mathrm{M})$ with deionised water.

\section{Synthesis of $\left\{\left[\mathrm{Cu}_{2}(\mu-O A c)_{4}\right][1,2-b i s(d i p h e n y l p h o s p h i n o) e t h a n e\right.$

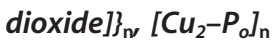

A mixture containing $\mathrm{Cu}(\mathrm{OAC})_{2} \cdot \mathrm{H}_{2} \mathrm{O}(0.056 \mathrm{~g}, 0.3 \mathrm{mmol})$ and methanol $(5 \mathrm{~mL})$ was added to a solution of 1,2-bis(DPPE) $(0.056 \mathrm{~g}$, $0.15 \mathrm{mmol})$ and $\mathrm{CH}_{2} \mathrm{Cl}_{2}(5 \mathrm{~mL})$. The reaction mixture was stirred for $3 \mathrm{~h}$ at room temperature and then was added to a solution of methanol $(5 \mathrm{~mL})$ and hydrogen peroxide $(0.0023 \mathrm{~mL}, 0.1 \mathrm{mmol})$. The solution was then stirred for $12 \mathrm{~h}$ at room temperature. After filtration, the filtrate was kept at room temperature for slow evaporation. Dark blue-coloured crystals of $\left[\mathrm{Cu}_{2}-\mathrm{P}_{\mathrm{o}}\right]_{n}$ were obtained in $78 \%$ yield. The crystals were filtered, washed with acetone, and dried in air. Elemental analysis calcd (\%) for $\mathrm{C}_{17} \mathrm{H}_{18} \mathrm{PO}_{5} \mathrm{Cu}$ : $\mathrm{C} 51.45$, H 4.56; found: C 51.50, H 4.61; IR (ATR): $\tilde{v}=1614,1436,1196,1123$, $745,729,676,633,625,500,470,418 \mathrm{~cm}^{-1}$ (Figure S3).

\section{Single-Crystal X-ray Diffraction}

Single-crystal $\mathrm{X}$-ray data on $\left[\mathrm{Cu}_{2}-\mathrm{P}_{\mathrm{o}}\right]_{n}$ was collected at $100 \mathrm{~K}$ on a Rigaku MicroMax 007HF diffractometer equipped with a monochromatic MoKa radiation source. The linear absorption coefficients, scattering factors for the atoms, and the anomalous dispersion corrections were taken from the International Tables for X-ray Crystallography. ${ }^{[36]}$ The data integration was performed with SAINT ${ }^{[37]}$ software. An empirical absorption correction was applied to the collected reflections with SADABS ${ }^{[38]}$ and the space group was determined based on systematic absences using XPREP. ${ }^{[39]}$ The structure was solved by the direct methods using SHELXTL-97 $7^{[00]}$ and refined on $\mathrm{F} 2$ by a full-matrix least-squares technique using the SHELXL-97 ${ }^{[41]}$ program package. All non-hydrogen atoms were refined anisotropically. The hydrogen atoms attached to carbon atoms were positioned geometrically and treated as riding atoms using SHELXL default parameters. Data collection, lattice parameters and structure solution parameters are collected in Table S1 and selective bond distances and angles are given in Table S2.

\section{Electrochemical Methods}

All electrochemical experiments were performed at room temperature and analysed with Gamry Instruments Interface 1000 potentiostat/galvanostat. A conventional three-electrode electrochemical cell was used with $\mathrm{Ag} / \mathrm{AgCl}(3.5 \mathrm{M} \mathrm{KCl})$ as a reference electrode, $\mathrm{Pt}$ wire as the counter electrode and FTO $(1 \times 2 \mathrm{~cm} ; 2 \mathrm{~mm}$ slides with $7 \Omega \mathrm{sq}^{-1}$ surface resistivity and $\approx 80 \%$ transmittance) as the working electrode. The FTO electrodes were cleaned by sonication in a basic soapy solution, deionised water and isopropanol for $15 \mathrm{~min}$ and dried, followed by annealing at $400^{\circ} \mathrm{C}$ for $30 \mathrm{~min}$. The catalyst was coated onto a FTO electrode by using a drop-casting method. A mixture of catalyst $(5 \mathrm{mg})$, methanol $(1000 \mu \mathrm{L})$ and Nafion $(100 \mu \mathrm{L})$ was sonicated for $30 \mathrm{~min}$. Then, sonicated suspension $(50 \mu \mathrm{L})$ was dropped onto a clean FTO electrode $\left(1 \mathrm{~cm}^{2}\right)$. The prepared electrode was dried in an $80^{\circ} \mathrm{C}$ oven for $10 \mathrm{~min}$ and further used for CV and bulk electrolysis. The electrode was rinsed with deionised water prior to use. All potentials reported in this paper were measured versus the $\mathrm{Ag} / \mathrm{AgCl}$ reference electrode. Cyclic voltammograms of $\left[\mathrm{Cu}_{2}-\mathrm{P}_{0}\right]_{n}$ coated on FTO were recorded with a scan rate of $50 \mathrm{mV} \mathrm{s}^{-1}$ in $\mathrm{KBi}(0.1 \mathrm{M})$ electrolyte with different $\mathrm{pH}$ values $(9.2,10.2,11.2$ and 12.2) between 0 and $1.5 \mathrm{~V}$ (vs. $\mathrm{Ag} / \mathrm{AgCl})$.

\section{Bulk Electrolysis}

Bulk water electrolysis was performed with a two-compartment cell separated with a glass frit. A Pt wire counter electrode was placed in one compartment and the FTO working electrode and a $\mathrm{Ag} / \mathrm{AgCl}$ reference electrode were placed in the other. The electrolysis experiments were performed in $\mathrm{KBi}$ solution at different $\mathrm{pH}$ values. Tafel data were collected under the same conditions at different applied potentials using a steady current density with an equilibrium time of $600 \mathrm{~s}$. Bulk electrolysis was performed at variable potentials without iR compensation.

\section{Faradaic Efficiency and Oxygen Evolution}

Oxygen evolution was determined with a YSI 5100 dissolvedoxygen-sensing instrument equipped with a dissolved-oxygen field probe inserted into the anodic compartment. The experiment was performed in a gas-tight electrochemical cell. The electrolyte was degassed by bubbling through high-purity $\mathrm{N}_{2}$ for 20 min with vigorous stirring. The catalyst coated on a FTO conductive surface was used as the working electrode. The reference electrode was positioned several millimetres from the working electrode. Measurements were recorded at $5 \mathrm{~min}$ intervals.

\section{X-ray Photoelectron Spectroscopy}

The elemental composition of the catalyst deposited on FTO and the oxidation states of those elements were probed by using a Thermo Scientific K-Alpha X-ray photoelectron spectrometer system operating with an AlK $\alpha$ microfocused monochromator source. The survey scan and the high-resolution $\mathrm{Cu} 2 \mathrm{p}$ spectra were obtained and spectra are referenced to the $C 1 s$ peak $(285.0 \mathrm{eV})$.

\section{X-ray Diffraction}

The crystal-phase analysis of the sample on the conductive side of FTO before and after bulk electrolysis was measured by XRD patterns were recorded by a Panalytical X'PertPro multipurpose X-ray diffractometer using CuK $\alpha$ radiation $(\lambda=1.5418 \AA \AA)$. The scanning rate was 5 degree $\mathrm{min}^{-1}$ from $20^{\circ}$ to $90^{\circ}$ in $2 \theta$.

\section{Raman Spectrometry}

Raman measurements were performed using a WITEC Alpha $300 \mathrm{~S}$ system. A diode-pumped solid-state $532 \mathrm{~nm}$ wavelength laser was used for excitation. The laser power was calibrated using a silicon photodiode at the sample plane.

\section{Acknowledgements}

The authors thank the Scientific and Technological Research Council of Turkey (TÜBITAK) for financial support (Project No. 


\section{Z095). E.Ü. thanks TÜBITAK for support (Project} 1929B011500059).

Keywords: copper paddle wheel · electrocatalysis · phosphine dioxide $\cdot$ water oxidation $\cdot \mathbf{X}$-ray diffraction

[1] a) H. Yoo, Y.-W. Choi, J. Choi, Chem CatChem 2015, 7, 643-647; b) M. Rodríguez, I. Romero, C. Sens, A. Llobet, J. Mol. Catal. A 2006, 251, $215-$ 220.

[2] a) S. Cherevko, T. Reier, A. R. Zeradjanin, Z. Pawolek, P. Strasser, K. J. J. Mayrhofer, Electrochem. Commun. 2014, 48, 81-85; b) A. Minguzzi, C. Locatelli, O. Lugaresi, E. Achilli, G. Cappelletti, M. Scavini, M. Coduri, P. Masala, B. Sacchi, A. Vertova, P. Ghigna, S. Rondinini, ACS Catal. 2015, 5 5104-5115; c) J. C. Hidalgo-Acosta, M. A. Méndez, M. D. Scanlon, H. Vrubel, V. Amstutz, W. Adamiak, M. Opallo, H. H. Girault, Chem. Sci. 2015, 6, $1761-1769$.

[3] a) G. Mattioli, P. Giannozzi, A. A. Bonapasta, L. Guidoni, J. Am. Chem. Soc 2013, 135, 15353-15363; b) M. Zhang, M. D. Respinis, H. Frei, Nat Chem. 2014, 6, 362-367; c) D. Wang, J. T. Groves, Proc. Natl. Acad. Sci. USA 2013, 110, 15579-15584; d) B. Das, A. Orthaber, S. Ott, A. Thapper, Chem. Commun. 2015, 51, 13074-13077; e) A. I. Nguyen, M. S. Ziegler, P. Oña-Burgos, M. Sturzbecher-Hohne, W. Kim, D. E. Bellone, T. D. Tilley, J. Am. Chem. Soc. 2015, 137, 12865-12872.

[4] a) M. Hatakeyama, H. Nakata, M. Wakabayashi, S. Yokojima, S. Nakamura, J. Phys. Chem. A 2012, 116, 7089-7097; b) K. Jin, J. Park, J. Lee, K. D. Yang, G. K. Pradhan, U. Sim, D. Jeong, H. L. Jang, S. Park, D. Kim, N.-E. Sung, S. H. Kim, S. Han, K. T. Nam, J. Am. Chem. Soc. 2014, 136, $7435-$ 7443; c) A. Han, H. Chen, Z. Sun, J. Xu, P. Du, Chem. Commun. 2015, 51, 11626-11629; d) R. Brimblecombe, D. R. J. Kolling, A. M. Bond, G. C. Dis mukes, G. F. Swiegers, L. Spiccia, Inorg. Chem. 2009, 48, 7269-7279.

[5] a) Y. Han, Y. Wu, W. Lai, R. Cao, Inorg. Chem. 2015, 54, 5604-5613; b) L. Wang, L. Duan, R. B. Ambre, Q. Daniel, H. Chen, J. Sun, B. Das, A. Thapper, J. Uhlig, P. Dinér, L. Sun, J. Catal. 2016, 335, 72-78; c) M. Zhang, M.T. Zhang, C. Hou, Z.-F. Ke, T.-B. Lu, Angew. Chem. Int. Ed. 2014, 53, 13042-13048; Angew. Chem. 2014, 126, 13258-13264.

[6] a) J. J. H. Pijpers, M. T. Winkler, Y. Surendranath, T. Buonassisi, D. G. Nocera, Proc. Natl. Acad. Sci. USA 2011, 108, 10056-10061; b) H. S. Ahn A. J. Bard, J. Am. Chem. Soc. 2015, 137, 612-615; c) S. K. Pilli, T.E. Furtak, L. D. Brown, T. G. Deutsch, J. A. Turnerc, A. M. Herring, Energy Environ. Sci. 2011, 4, 5028-5034.

[7] a) X.-B. Han, Z.-M. Zhang, T. Zhang, Y.-G. Li, W. Lin, W. You, Z.-M. Su, E.-B. Wang, J. Am. Chem. Soc. 2014, 136, 5359-5366; b) J. Soriano-López, S Goberna-Ferrón, L. Vigara, J. J. Carbó, J. M. Poblet, J. R. Galán-Mascarós Inorg. Chem. 2013, 52, 4753-4755; c) J. J. Stracke, R. G. Finke, J. Am. Chem. Soc. 2011, 133, 14872-14875.

[8] D. Wang, G. Ghirlanda, J. P. Allen, J. Am. Chem. Soc. 2014, 136, $10198-$ 10201.

[9] B. J. Deibert, J. Zhang, P. F. Smith, K. W. Chapman, S. Rangan, D. Banerjee, K. Tan, H. Wang, N. Pasquale, F. Chen, K.-B. Lee, G. C. Dismukes, Y. J. Chabal, J. Li, Chem. Eur. J. 2015, 21, 14218-14228.

[10] R. L. Lieberman, D. B. Shrestha, P. E. Doan, B. M. Hoffman, T. L. Stemmler, A. C. Rosenzweig, Proc. Natl. Acad. Sci. USA 2003, 100, 3820-3825.

[11] D. Horn, A. Barrientos, IUBMB Life 2008, 60, 421-429.

[12] S. M. Barnett, K. I. Goldberg, J. M. Mayer, Nat. Chem. 2012, 4, 498-502.

[13] Z. Chen, T. J. Meyer, Angew. Chem. Int. Ed. 2013, 52, 700-703; Angew. Chem. 2013, 125, 728-731.

[14] J. S. Pap, Ł. Szyrwiel, D. Srankó, Z. Kerner, B. Setner, Z. Szewczuk, W. Malink, Chem. Commun. 2015, 51, 6322-6324.

[15] a) C. Lu, J. Wang, Z. Chen, ChemCatChem 2016, 8, 2165-2170; b) X. Liu, S. Cui, M. Qian, Z. Sun, P. Du, Chem. Commun. 2016, 52, 5546-5549.

[16] T. Zhang, C. Wang, S. Liu, J.-L. Wang, W. Lin, J. Am. Chem. Soc. 2014, $136,273-281$.
[17] X. Liu, S. Cui, Z. Sun, Y. Ren, X. Zhang, P. Du, J. Phys. Chem. C 2016, 120, $831-840$.

[18] a) B. Shankar, P. Elumalai, R. Shanmugam, V. Singh, D. T. Masram, M. Sathiyendiran, Inorg. Chem. 2013, 52, 10217-10219; b) A.-F. Shihada, F. Weller, Z. Naturforsch. B 1996, 51, $1111-1116$; c) J. Beckmann, D. Dakternieks, A. Duthie, C. Mitchell, F. Ribot, J. B. d'Espinose de la Caillerie, B. Revel, Appl. Organomet. Chem. 2004, 18, 353-358; d) M. Hatano, E. Takagi, K. Ishihara, Org. Lett. 2007, 9, 4527-4530; e) Y. Hasegawa, R. Hieda, T. Nakagawa, T. Kawai, Helv. Chim. Acta 2009, 92, 2238-2248; f) D. Rosario-Amorin, S. Ouizem, D. A. Dickie, R. T. Paine, R. E. Cramer, B. P. Hay, J. Podair, L. H. Delmau, Inorg. Chem. 2014, 53, 5698-5711.

[19] a) Y. Yan, M. Juríček, F.-X. Coudert, N. A. Vermeulen, S. Grunder, A. Dailly, W. Lewis, A. J. Blake, J. F. Stoddart, M. Schröder, J. Am. Chem. Soc. 2016, 138, 3371-3381; b) C.-S. Liu, J.-J. Wang, I.-F. Yan, Z. Chang, X.-H. Bu, E. C. Sañudo, J. Ribas, Inorg. Chem. 2007, 46, 6299-6310.

[20] K. Takahashi, N. Hoshino, T. Takeda, S.-I. Noro, T. Nakamura, S. Takeda, T. Akutagawa, Inorg. Chem. 2015, 54, 9423-9431.

[21] F. P. W. Agterberg, H. A. J. Provó Kluit, W. L. Driessen, H. Oevering, W. Buijs, M. T. Lakin, A. L. Spek, J. Reedijk, Inorg. Chem. 1997, 36, 4321 4328.

[22] Y. Zhao, D.-S. Deng, L.-F. Ma, B.-M. Jib, L.-Y. Wang, Chem. Commun. 2013, 49, 10299-10301.

[23] J. B. Gerken, J. G. McAlpin, J. Y. C. Chen, M. L. Rigsby, W. H. Casey, R. D. Britt, S. S. Stahl, J. Am. Chem. Soc. 2011, 133, 14431-14442.

[24] J. Du, Z. Chen, S. Ye, B. J. Wiley, T. J. Meyer, Angew. Chem. Int. Ed. 2015 54, 2073-2078; Angew. Chem. 2015, 127, 2101-2106.

[25] F. Yu, F. Li, B. Zhang, H. Li, L. Sun, ACS Catal. 2015, 5, 627-630.

[26] X. Liu, H. Zheng, Z. Sun, A. Han, P. Du, ACS Catal. 2015, 5, 1530-1538.

[27] T.-T. Li, S. Cao, C. Yang, Y. Chen, X.-J. Lv, W.-F. Fu, Inorg. Chem. 2015, 54, $3061-3067$.

[28] a) A. S. Duke, E. A. Dolgopolova, R. P. Galhenage, S. C. Ammal, A Heyden, M. D. Smith, D. A. Chen, N. B. Shustova, J. Phys. Chem. C 2015, 119, 27457-27466; b) D. Deng, T. Qi, Y. Cheng, Y. Jin, F. Xiao, J. Mater. Sci. Mater. Electron. 2014, 25, 390-397.

[29] S.-M. Chang, C.-Y. Hou, P.-H. Lo, C.-T. Chang, Appl. Catal. B 2009, 90, 233-241.

[30] a) J. Morales, L. Sánchez, F. Martín, J. R. Ramos-Barrado, M. Sánchez, Electrochim. Acta 2004, 49, 4589-4597; b) C. D. Wagner, W. M. Riggs, L. E. Davis, J. F. Moulder in Handbook of X-ray Photoelectron Spectroscopy: A Reference Book of Standard Data for Use in X-ray Photoelectron Spectroscopy (Ed.: G. E. Muilenberg), PerkinElmer Corp., Physical Electronics Division, Eden Prairie, MN, 1979, p. 82.

[31] E. Cano, C. L. Torres, J. M. Bastidas, Mater. Corros. 2001, 52, 667-676.

[32] Y. Chen, W. Liu, C. Ye, L. Yu, S. Qi, Mater. Res. Bull. 2001, 36, 2605-2612.

[33] B. K. Park, S. Jeong, D. Kim, J. Moon, S. Lim, J. S. Kim, J. Colloid Interface Sci. 2007, 311, 417-424.

[34] K. Asami, K. Hashimoto, S. Shimodaira, Corros. Sci. 1978, 18, 151-160.

[35] K. S. Joya, H. J. M. de Groot, ACS Catal. 2016, 6, 1768-1771.

[36] International Tables for X-Ray Crystallography, Kynoch Press, Vol. III, Birmingham, UK, 1952.

[37] SAINT, version 6.02, Bruker AXS, Madison, WI, 1999.

[38] G. M. Sheldrick, SADABS, Empirical Absorption Correction Program; University of Göttingen: Göttingen, Germany, 1997.

[39] XPREP, version 5.1; Siemens Industrial Automation Inc., Madison, WI, 1995.

[40] G. M. Sheldrick, SHELXTL Reference Manual, version 5.1, Bruker AXS: Madison, WI, 1997.

[41] G. M. Sheldrick, SHELXL-97: Program for Crystal Structure Refinement; University of Göttingen, Göttingen, Germany, 1997.

Manuscript received: August 26, 2016

Accepted Article published: September 12, 2016

Final Article published: September 28, 2016 